ORIGINAL ARTICLES

\title{
Evaluation of the Hypoglycaemic Activity of Petiveria alliacea (Guinea Hen Weed) Extracts in Normoglycaemic and Diabetic Rat Models
}

\author{
S-L Christie, A Levy
}

\begin{abstract}
Objective: Petiveria alliacea (P alliacea) has ethno-traditional use as a hypoglycaemic agent in Jamaica and is yet to be scientifically validated as such. Therefore, extracts of aerial parts of the plant were evaluated for hypoglycaemic activity in normoglycaemic and diabetic rats.

Methods: Aqueous and hexane extracts prepared from leaves of $\mathrm{P}$ alliacea were tested for hypoglycaemic activity. An acute administration of the extracts (200 and $400 \mathrm{mg} / \mathrm{kg}$ body weight) was evaluated in normoglycaemic rats. Additionally, the hypoglycaemic effect of sub-chronic administration was assessed in streptozotocin-induced diabetic rats. Blood glucose was recorded using a glucometer and test strips. Data were analysed using Student's t-test ( $\mathrm{p} \leq 0.05)$.

Results: The aqueous and hexane extracts demonstrated no significant reduction of fasting blood glucose $(F B G)$ and no significant improvement of glucose tolerance in normal rats. The aqueous extract ( $400 \mathrm{mg} / \mathrm{kg}$ body weight) increased FBG from $4.75 \pm 0.28 \mathrm{mmol} / \mathrm{L}$ to $5.88 \pm 0.46$ when compared to control ( $\mathrm{p} \leq 0.001)$. In diabetic rats, the hexane extract $(400 \mathrm{mg} / \mathrm{kg}$ body weight) caused reduction of FBG after two weeks of treatment $(p \leq 0.010)$, but this was not sustained. The aqueous extract showed no reduction of FBG in diabetic rats.

Conclusion: The aqueous extract of $\mathrm{P}$ alliacea demonstrated a hyperglycaemic effect in normoglycaemic rats and showed no hypoglycaemic activity in diabetic rats. The hexane extract caused no hypoglycaemic action in normal rats and failed to sustain an initial hypoglycaemic action in diabetic rats. This study presents evidence that does not support significant hypoglycaemic activity of $\mathrm{P}$ alliacea; this could hold significant implications for its use in ethno-traditional medicine.
\end{abstract}

Keywords: Extract, hypoglycaemic, Petiveria alliacea, rats

\section{Evaluación de la Actividad Hipoglicémica de los Extractos de Petiveria alliacea (Yerba de Guinea o Anamú) en Modelos de Ratas Diabéticas y Normoglicémicas

\author{
S-L Christie, A Levy
}

\begin{abstract}
RESUMEN
Objetivo: Petiveria alliacea ( $\mathrm{P}$ alliacea) tiene uso etnotradicional como agente hipoglicémico en Jamaica, y todavía requiere ser validado cientificamente. Por lo tanto, extractos de las partes aéreas de la planta fueron evaluados en relación con su actividad hipoglicémica en ratas normoglicémicas y diabéticas.

Métodos: Extractos acuosos y extractos de hexanos preparados a partir de hojas de $\mathrm{P}$ alliacea fueron sometidos a prueba a fin de detectar su actividad hipoglicémica. Se evaluó el efecto de una administración aguda de los extractos (200 y $400 \mathrm{mg} / \mathrm{kg}$ de peso corporal) en ratas normoglicémicas.
\end{abstract}

From: Department of Basic Medical Sciences, Pharmacology Section, The University of the West Indies, Kingston 7, Jamaica, West Indies.
Correspondence: Dr A Levy, Department of Basic Medical Sciences, Pharmacology Section, The University of the West Indies, Kingston 7, Jamaica, West Indies. Fax: 1876-977-3823, e-mail: arkene_levy@yahoo. com 
Además, se evaluó el efecto hipoglicémico de la administración subcrónica en ratas con diabetes inducida por estreptozotocina. La glucosa en sangre fue registrada usando un glucómetro y tiras reactivas. Los datos se analizaron mediante la prueba $t$ de Student $(p \leq 0.05)$.

Resultados: Los extractos acuosos y los extractos de hexano no mostraron reducción significativa alguna de la glucemia en ayunas (GA), ni tampoco ninguna mejora significativa de la tolerancia a la glucosa en ratas normales. El extracto acuoso (400 $\mathrm{mg} / \mathrm{kg}$ de peso corporal) aumentó la $\mathrm{GA}$ de 4,75 \pm $0,28 \mathrm{mmol} / \mathrm{L}$ a 5,88 $\pm 0,46$ en comparación con el control ( $p \leq 0.001)$. En las ratas diabéticas, el extracto de hexano $(400 \mathrm{mg} / \mathrm{kg}$ de peso corporal), trajo por consecuencia la reducción de GA tras dos semanas de tratamiento $(p \leq 0.010)$, pero este efecto no se mantiene. El extracto acuoso no mostró ninguna reducción de $G A$ en las ratas diabéticas.

Conclusión: El extracto acuoso de $\mathrm{P}$ alliacea mostró un efecto hiperglicémico en las ratas normoglicémicas, y no mostró ninguna actividad hipoglicémica en las ratas diabéticas. El extracto de hexano no produjo ninguna acción hipoglicémica en ratas normales, y no mantuvo la acción hipoglicémica inicial en las ratas diabéticas. Este estudio presenta evidencias que no respaldan una actividad hipoglicémica significativa de $\mathrm{P}$ alliacea, lo cual podría tener importantes implicaciones para su uso en la medicina etnotradicional.

Palabras claves: Extracto, hipoglicémica, Petiveria alliacea, ratas

West Indian Med J 2013; 62 (8): 686

\section{INTRODUCTION}

Diabetes mellitus is a multifarious metabolic disease typified by chronic hyperglycaemia featuring disturbances in carbohydrate, fat and protein metabolism (1). The disease results from an absolute or relative deficiency in insulin secretion and/or insulin action (1). The major classifications are Type 1 diabetes which results from an autoimmune destruction of pancreatic beta cells and Type 2 diabetes which occurs because of the body's ineffective use of insulin, also known as insulin resistance (2).

The main objective of diabetic therapy is to reduce hyperglycaemia which lessens the incidence of morbidity and mortality (3). Diabetic therapy involves lifestyle interventions such as proper dieting and regular exercise coupled with the use of medications such as insulin and/or oral hypoglycaemic agents (3). Insulin and its analogs are compulsory in the management of Type 1 diabetes and may be introduced in Type 2 therapy when glycaemic control is poorly managed. Type 2 diabetic therapy involves the use of oral hypoglycaemic agents which fall into five major categories of either sulfonylureas, thiazolidinediones, meglitinides, biguanides and alpha-glucosidase inhibitors (3).

For Type 1 diabetes, several limitations are associated with insulin therapy including ineffectiveness on oral administration, the need for constant refrigeration, and fatal hypoglycaemia in the event of excess dosage (4). In the case of Type 2 diabetic therapy, oral anti-diabetic medications frequently lose their efficacy in a number of patients (3) and some medications can present with moderate to severe adverse effects. Sulfonylureas and meglitinides can cause hypoglycaemia and weight gain (3); thiazolidinediones are reported to increase risk of cardiovascular events and liver toxicity (3), while biguanides such as metformin commonly cause lactic acidosis (5).
The undesirable effects associated with conventional medications underlie the constant exploration for new drugs with safer profiles. Scientific studies have validated the efficacy of over 1200 plant species in the treatment of diabetes mellitus $(6,7)$. Herbs used as therapy are speculated to have minimal undesirable effects and may be helpful in managing the various complications of this disease which include retinopathy, nephropathy, neuropathy and cardiovascular disease $(3,8)$.

Petiveria alliacea, commonly known as guinea hen weed or anamu, is a perennial shrub which grows wildly in the South and Central American tropics, Africa and the Caribbean (9). It belongs to the family Phytolaccaceae and is used in ethnotraditional medicine in Cuba and Jamaica for purported hypoglycaemic properties in diabetes. Various extracts and fractions of the plant have shown biological activity, namely analgesic and anti-inflammatory (10), anticancer (11), anti-microbial (12), abortive (13) and hypoglycaemic properties (14).

The usefulness of $P$ alliace as a hypoglycaemic agent has not been widely studied and earlier investigations present conflicting glycaemic activity $(9,14)$. Further experimental studies are required to finally establish its usefulness as a traditional anti-diabetic remedy. On this basis, the present study evaluated the hypoglycaemic activity of an aqueous and hexane extract of $P$ alliacea in normoglycaemic and diabetic rats.

\section{MATERIAL AND METHODS \\ Plant}

Leaves of $P$ alliacea were collected from Taylor Hall grounds at The University of the West Indies (UWI), Mona Campus, Jamaica. Leaves were identified and authenticated by $\mathrm{Mr}$ Michael Lewis of the Botany Department and accession number 35403 received. 
The dried powdered leaves were extracted in a soxhlet apparatus with hexane for 72 hours. The mixture was concentrated using a rotary evaporator forming a thick paste/ slurry which was stored in a freezer for later use. The slurry was redistributed in mineral oil for dosing.

The aqueous extract was prepared by boiling the powder in distilled water at a ratio 1:10 (w/v) for five to seven minutes. The mixture was filtered using a cheese cloth, concentrated and frozen before placing on the freeze dry machine. A dark green powder was produced. The powder was re-dissolved in distilled water for dosing.

\section{Animals}

Adult male Sprague Dawley rats ( 350-500 g) were procured from The UWI Animal House. Animals were housed in meshed metal cages and maintained under standard temperature of $25-30{ }^{\circ} \mathrm{C}$, light and dark cycles of 12 hours. Animals were fed standard rat chow and tap water ad libitum.

Ethical approval was obtained from the University Hospital of the West Indies/University of the West Indies/ Faculty of Medical Sciences Ethics Committee. The experimental protocol conformed to the guidelines for animal care and use of the institution.

\section{Fasted normoglycaemic model}

The effects of single oral administration of aqueous and hexane extracts were assessed in fasted normoglycaemic rats at two dose levels (200 and $400 \mathrm{mg} / \mathrm{kg}$ bodyweight [bwt]) on separate days. Animals ( $n=6$ per group) were fasted overnight for 16 hours. Blood glucose was recorded before dosing and then at 30-minute intervals for three hours following administration. Blood was collected from the tail vein and glucose levels estimated using a test meter and test strips [Accu-Chek Active ${ }^{\circledR}$ test meter and test strips: Roche Pharmaceuticals] $(15,16)$. Controls received a single oral dose of glibenclamide (10 mg/kg bwt) [Sigma-Aldrich Company] or vehicle $(1 \mathrm{ml} / \mathrm{kg} \mathrm{bwt})$.

\section{Glucose loaded normoglycaemic model}

A single oral dose of aqueous and hexane extracts at two dose levels (200 and $400 \mathrm{mg} / \mathrm{kg}$ bwt) were tested in oral glucose loaded rats. Each dose was administered on separate days. The extracts were administered 15 minutes before glucose load (2 g/kg bwt); blood glucose was recorded before treatment and then at 30-minute intervals for three hours. Blood glucose estimates were done using Accu-Chek Active $^{\circledR}$ test meter and test strips. Controls received a single oral dose of glibenclamide $(10 \mathrm{mg} / \mathrm{kg}$ bwt) or vehicle (1 $\mathrm{ml} / \mathrm{kg}$ bwt). Each group comprised six rats.

\section{Streptozotocin-induced diabetic model}

Experimental diabetes was induced via a single intraperitoneal (ip) injection of freshly prepared streptozotocin (50 $\mathrm{mg} / \mathrm{kg}$ bwt) [Sigma-Aldrich Company] in overnight fasted rats (17). Streptozotocin was prepared in distilled water. Animals with fasting blood glucose $(\mathrm{FBG})>7 \mathrm{mmol} / \mathrm{L}$ were selected for a glibenclamide challenge to determine the type of diabetes induced. The animals were unresponsive to glibenclamide and were determined to be Type 1 diabetic.

The diabetic rats were divided into four groups $(n=5)$ : group 1 was given aqueous extract ( $200 \mathrm{mg} / \mathrm{kg}$ bwt), group 2 was given hexane extract (400 mg/kg bwt), group 3 was a negative diabetic control given distilled water $(1 \mathrm{ml} / \mathrm{kg}$ bwt $)$ and group 4 was a positive diabetic control given insulin (Sigma-Aldrich Company) as an ip dose of $15 \mathrm{IU} / \mathrm{kg}$ bwt. Each group received a daily dose of their treatment for three weeks. The changes in blood glucose levels were recorded at the end of each week.

\section{Statistical analysis}

SPSS version 17 was the statistical software used. Results were expressed as mean \pm SEM. The Student's $t$-test was used to determine significance between the mean of the control and treatment groups. Statistical significance was observed at $p \leq 0.05$.

\section{RESULTS}

Effect of Palliacea on FBG levels in normoglycaemic rats The aqueous (Fig. 1) and hexane extracts (Fig. 2) showed no

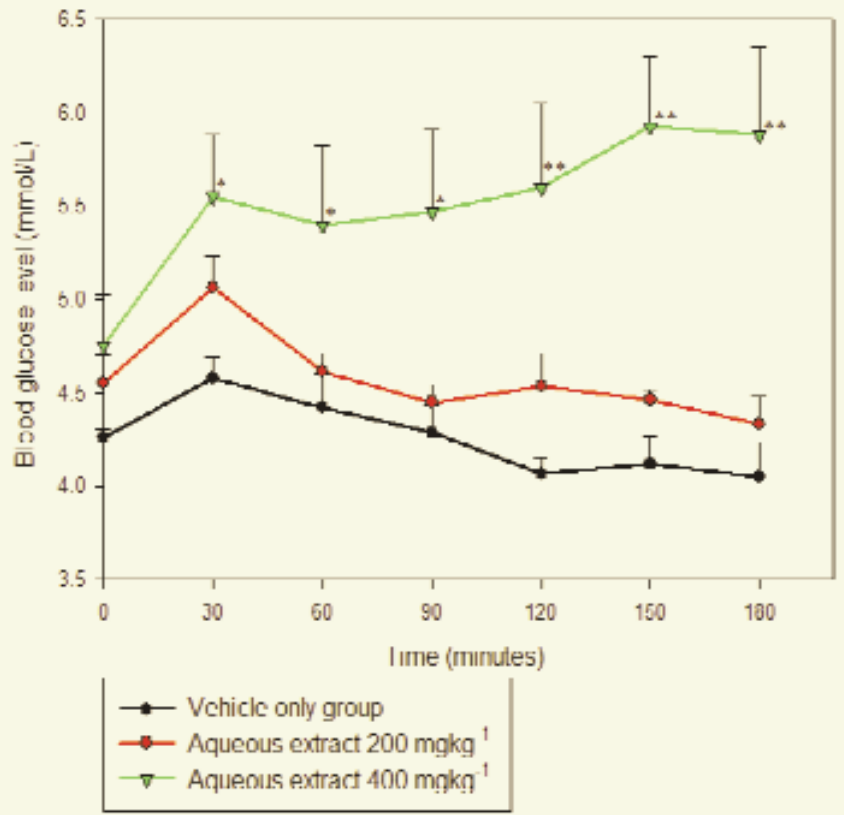

Fig. 1: Effect of aqueous extract of $P$ alliacea on fasting blood glucose (FBG) levels in normoglycaemic rats. Asterisks represent significance as compared to vehicle treated group $\left(* p \leq 0.05\right.$ and ${ }^{* *} p \leq$ 0.01)

significant reduction of blood glucose concentration in fasted normoglycaemic rats. The aqueous extract $(400 \mathrm{mg} / \mathrm{kg})$ caused a gradual increase in FBG $(p \leq 0.001)$. Glibenclamide (Fig. 3), a reference drug, produced the expected decline in FBG $(p \leq 0.004)$. 


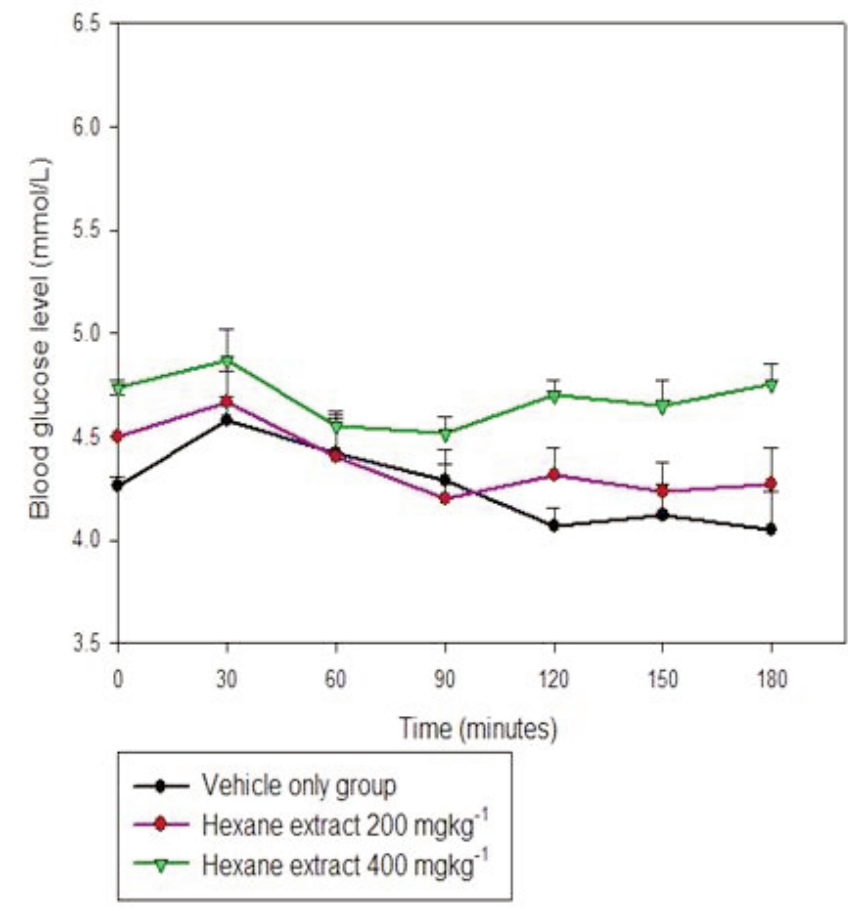

Fig. 2: Effect of hexane extract of $P$ alliacea on fasting blood glucose levels in normoglycaemic rats.

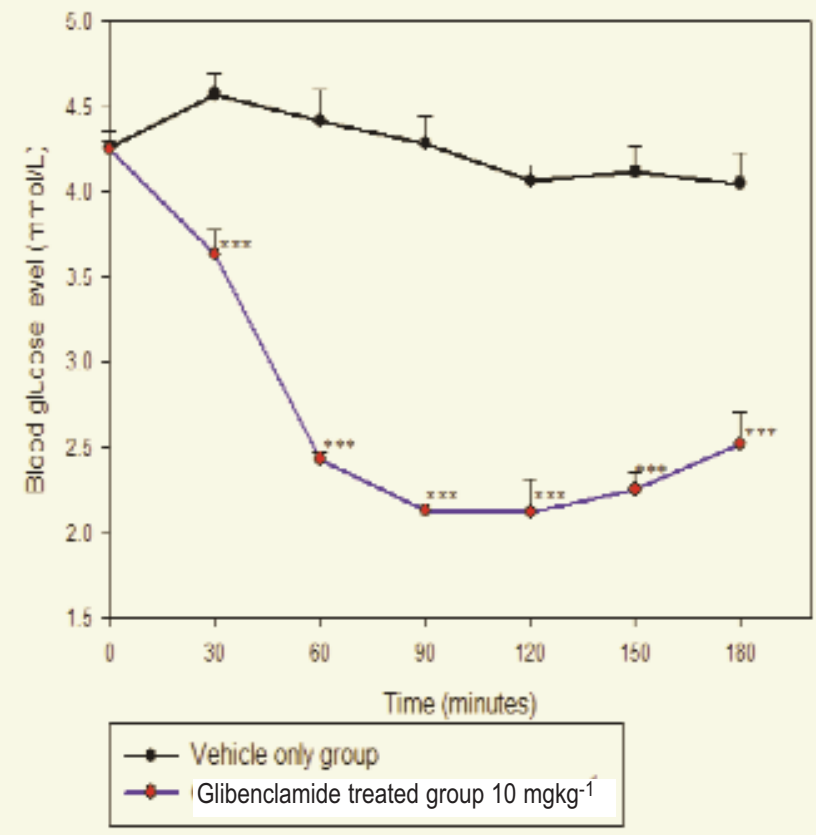

Fig. 3: Effect of glibenclamide on fasting blood glucose (FBG) levels in normoglycaemic rats. Asterisks represent significance as compared to vehicle treated group $(* * * p \leq 0.001)$.

Effect of $P$ alliacea in glucose loaded normoglycaemic rats Both aqueous (Fig. 4) and hexane extracts (Fig. 5) caused no significant overall improvement in glucose tolerance.

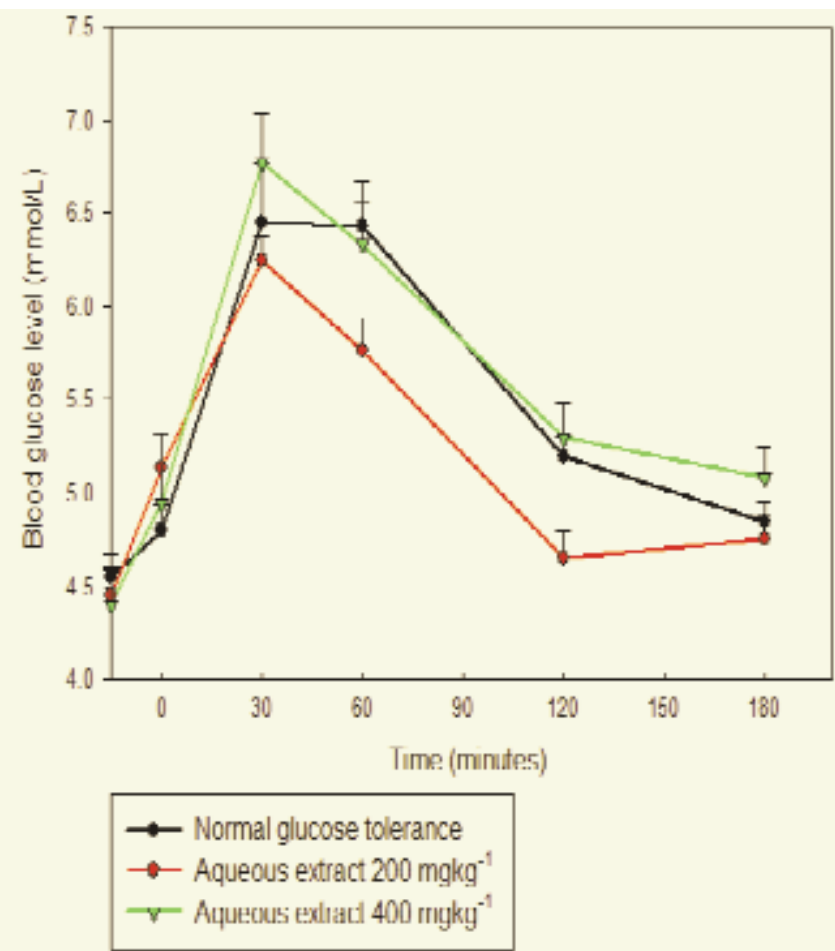

Fig. 4: Effect of aqueous extract of $P$ alliacea in glucose loaded normoglycaemic rats.

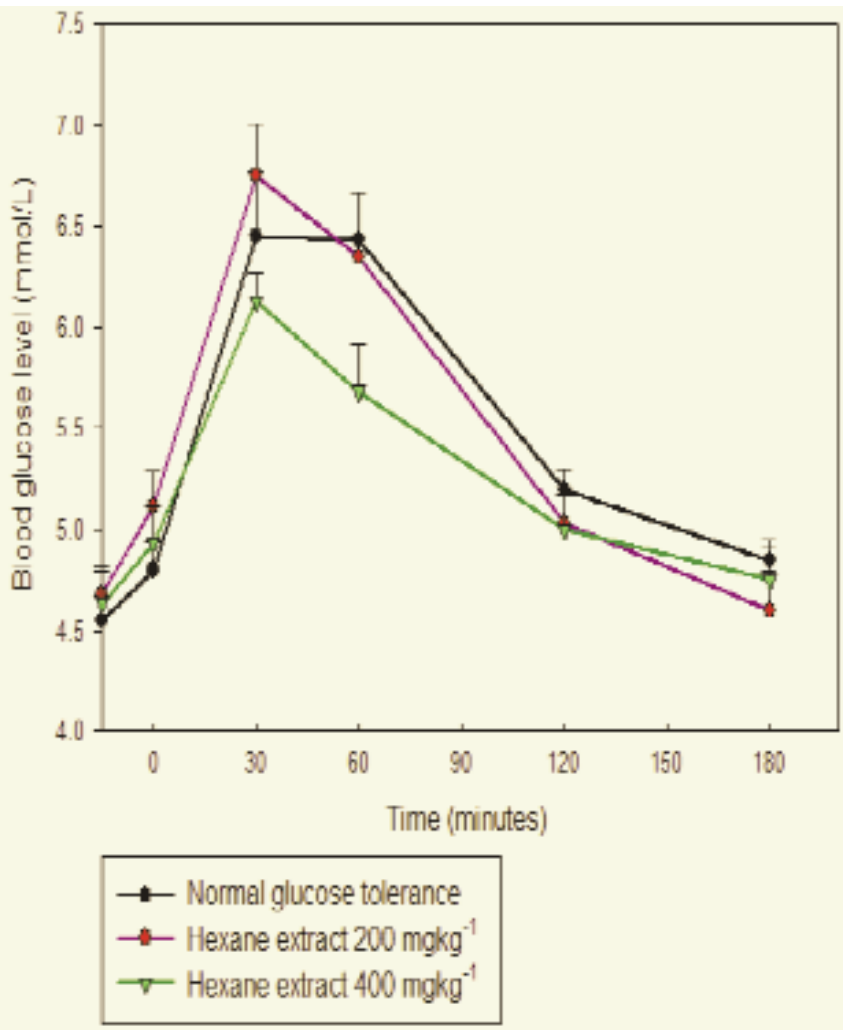

Fig. 5: Effect of hexane extract of $P$ alliacea in glucose loaded normoglycaemic rats. 
Glibenclamide improved glucose tolerance $(p \leq 0.012)$ and also inhibited the peak seen after glucose load (Fig. 6).

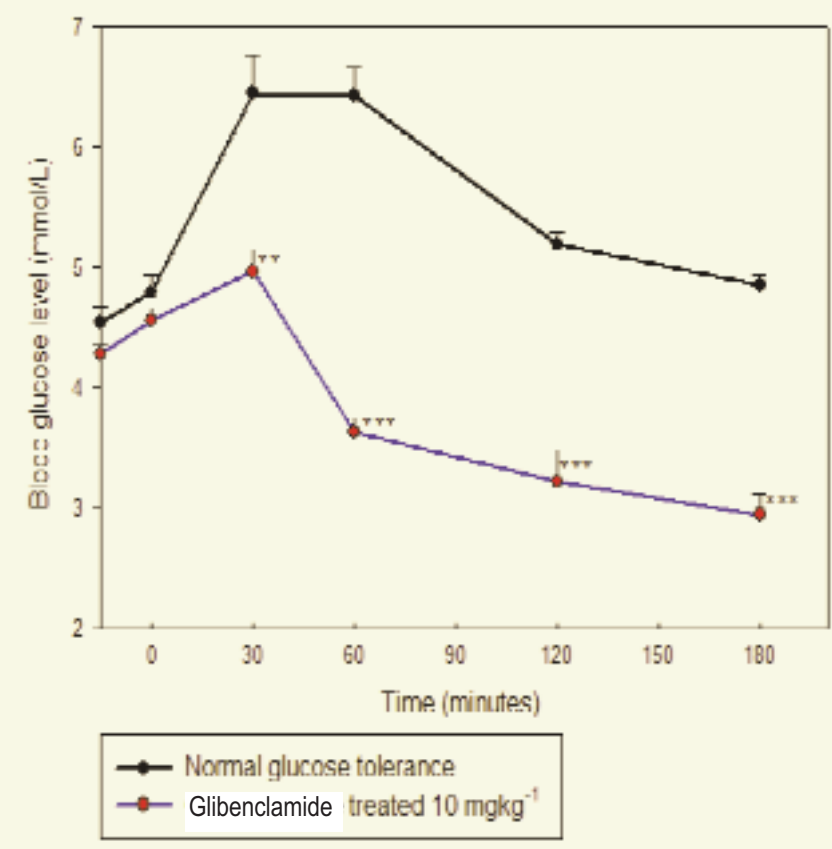

Fig. 6: Effect of glibenclamide in glucose loaded normoglycaemic rats. Asterisks represent significance as compared to the normal glucose tolerance $(* * p=0.002, * * * p \leq 0.0001)$

Effect of $P$ alliacea on $F B G$ in streptozotocin-induced diabetic rats

The aqueous extract $(200 \mathrm{mg} / \mathrm{kg}$ bwt $)$ caused no significant hypoglycaemic effect in streptozotocin-induced diabetic rats. Instead, blood glucose increased weekly throughout the experiment. Fasting blood glucose levels moved from $16.62 \pm$ $2.34 \mathrm{mmol} / \mathrm{L}$ to $24.62 \pm 1.66 \mathrm{mmol} / \mathrm{L}(p \leq 0.048)$ [Fig. 7].

The hexane extract $(400 \mathrm{mg} / \mathrm{kg}$ bwt) caused a significant reduction in FBG in diabetic rats in week 2 when compared to the diabetic control $(p=0.010)$. This effect, however, was not sustained as no further reduction in blood glucose was observed in week 3. Blood glucose moved from $15.44 \pm 2.94 \mathrm{mmol} / \mathrm{L}$ to $18.14 \pm 2.72$ initially and significantly declined to $9.22 \pm 2.94$ by week 2 . Blood glucose level gradually rose again to $15.12 \pm 3.64 \mathrm{mmol} / \mathrm{L}$ at the end of week 3 (Fig. 8). The insulin treated diabetic group showed the expected reduction in blood glucose levels. At the end of week 1, glucose levels started to decrease $(p=0.042)$. For weeks 2 and 3, significant reductions in glucose levels were observed: $p<0.0001$ and $p=0.003$, respectively (Fig. 9).

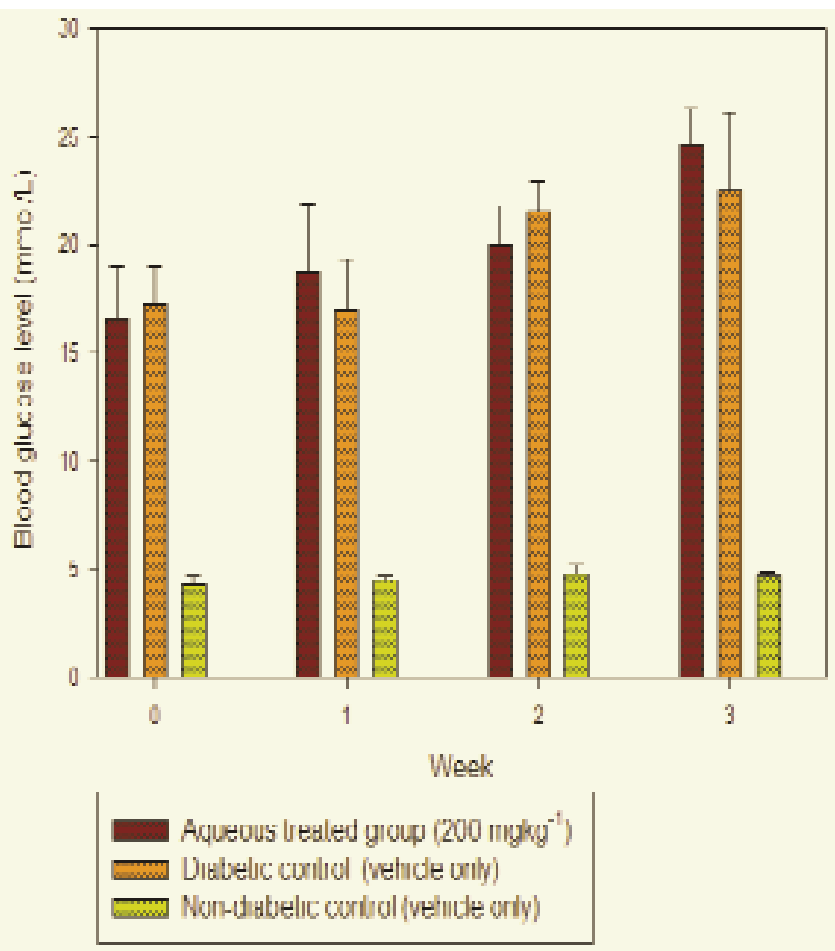

Fig. 7: Effect of aqueous extract of Palliacea on blood glucose levels in streptozotocin-induced diabetic rats.

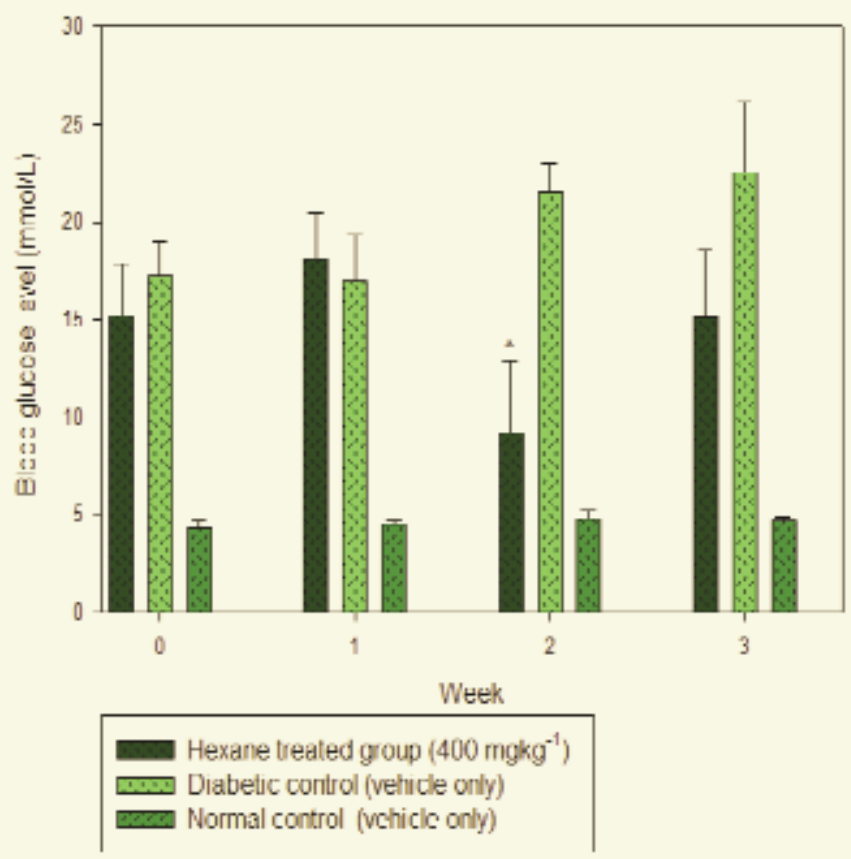

Fig 8: $\quad$ Effect of hexane extract of $P$ alliacea on blood glucose levels in streptozotocin-induced diabetic rats. Asterisk show significant difference when compared to diabetic control given vehicle only $(*$ $p=0.010)$ 


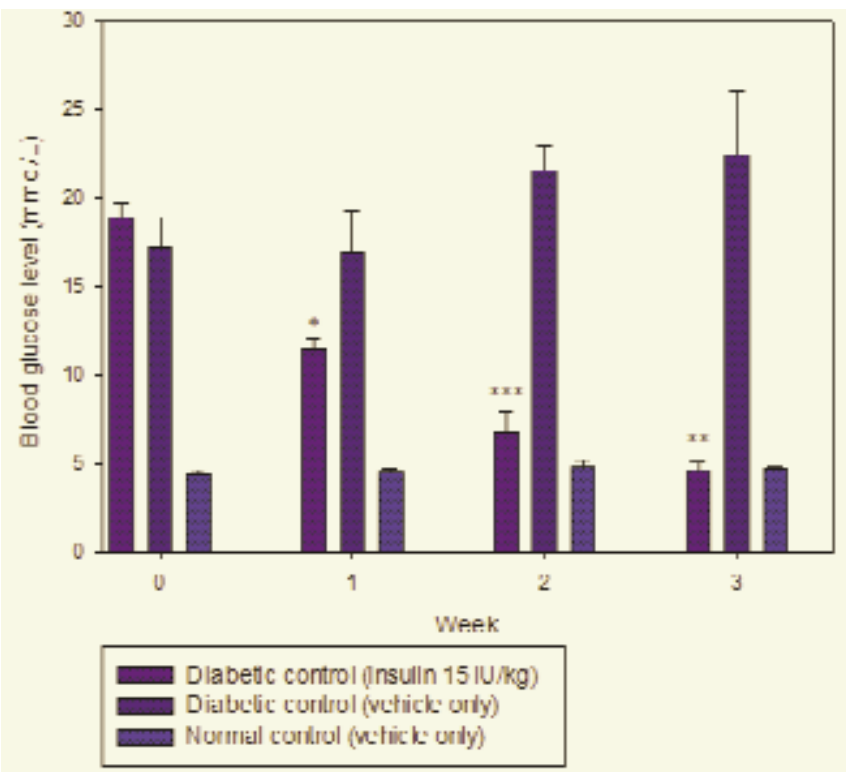

Fig. 9: Effect of insulin on blood glucose levels in streptozotocin-induced diabetic rats. Asterisk show significant difference when compared to diabetic control given vehicle only $\left(* p=0.043,{ }^{* *} p<0.0001\right.$, $* * * p=0.003)$.

\section{DISCUSSION}

The targeted screening of plant materials for anti-diabetic activity has increased globally, driven significantly by the limitations of current oral anti-diabetic agents (6). The preliminary screening of plant extracts in normoglycaemic rats is an established approach for determining glycaemic effects when there is normal pancreatic activity (18). These studies are subsequently followed by assessment in diabetic rat models $(17,19)$. This was the approach in the present study as we investigated the hypoglycaemic activity of $P$ alliacea extracts in normal and diabetic rats.

Phytochemical testing of $P$ alliacea has revealed bioactive compounds such as coumarins, triterpenes, flavonoids (20), cysteine sulfoxide derivatives $(21,22)$, steroids, saponins, polyphenols and tannins (23) in extracts of varying polarities. Therefore, for our study, aqueous and hexane extracts were prepared to determine the potential glycaemic outcome of different compounds across varying polarities and also to remain consistent with earlier studies which have reported pharmacological activities (24).

The current study revealed that the aqueous extract at $200 \mathrm{mg} / \mathrm{kg}$ and $400 \mathrm{mg} / \mathrm{kg}$ demonstrated no hypoglycaemic effect in a fasted rat model. Our results challenge previously reported findings by Lores and Cires Pujol (14) which showed an aqueous extract producing a $60 \%$ decline in blood glucose levels in fasted mice. It is important, however, to highlight that the contrasting glycaemic outcomes from our study versus that of Lores and Cires Pujol (14) may arise because of differences in sample preparation and conditions. The aqueous extract at $400 \mathrm{mg} / \mathrm{kg}$ caused a significant ele- vation of FBG ( $p \leq 0.01)$; this effect was similar to a study by García-González et al (9). The study reported a hyperglycaemic effect of $P$ alliacea in mice. The results from GarcíaGonzález et al (9) and our work suggest that the aqueous extract of $P$ alliacea has a hyperglycaemic profile in normoglycaemic mice and rats. A high sugar content of the extract at higher doses could explain the hyperglycaemia observed, however, further chemical analysis is required to confirm this. Additionally, the hexane extracts caused no significant reduction in blood glucose. This therefore confirmed that both extracts of $P$ alliacea do not exhibit hypoglycaemic activity in normoglycaemic rats.

In the glucose loaded model, there was no improvement in glucose tolerance upon administration of either extract, suggesting that the extracts do not promote insulin secretion from beta cells and are unable to inhibit the peak in glucose levels.

For the diabetic studies, a single dose of each extract was selected. The lower dose of the aqueous extract was chosen because it produced the most notable response in the glucose loaded model (Fig. 4). The higher dosage for the hexane extract was selected since it produced the most notable response in the glucose loaded model (Fig. 5). During the diabetic study, the hexane extract $(400 \mathrm{mg} / \mathrm{kg})$ reduced glucose levels in week $2(p=0.010)$, however, this effect was not sustained. This transient hypoglycaemic effect may be due in part to a reduction in the rate of intestinal glucose absorption or an increase in peripheral glucose utilization as this is commonly observed in the rodent models of streptozotocin-induced diabetic models (25). Further, several flavonoids including quercetin which are present in the leaves of $P$ alliacea (20) have been shown to reduce intestinal glucose absorption (26-28) and one plausible explanation for the unsustained hypoglycaemic effect seen with our extract could be inefficient inhibition of the sugar transporter GLUT2 by these flavonoids (26). Finally, in our positive control group, insulin maintained the expected glycaemic range by producing a significant reduction in blood glucose levels over the treatment period $(p \leq 0.042)$.

\section{CONCLUSION}

When viewed collectively, no significant hypoglycaemic profile was established for $P$ alliacea. Furthermore, a hyperglycaemic effect was observed with the aqueous extract at high dose. These findings hold significant implications for the ethno-traditional use of $P$ alliacea as a hypoglycaemic agent where it is used in an aqueous form.

\section{ACKNOWLEDGEMENT}

The authors would like to acknowledge the Research and Publications Section at The University of the West Indies Mona Campus, Jamaica for providing funding. 


\section{REFERENCES}

1. Alberti K, Zimmet P. Definition, diagnosis and classification of diabetes mellitus and its complications. Part 1: diagnosis and classification of diabetes mellitus provisional report of a WHO consultation. Diabet Med 1998; 15: 539-53.

2. American Diabetes Association. Diagnosis and classification of diabetes mellitus. Diabetes Care 2012; 35: S64-S71.

3. Dey L, Attele A, Yuan C. Alternative therapies for type 2 diabetes. Altern Med Rev 2002; 7: 45-58.

4. Tango Y, Abdelaziz M, Adelaiye A, Fatihu M, Musa K. Effects of hydromethanolic leaves extract of indigofera pulchra on blood glucose levels of normoglycemic and alloxan induced diabetic wistar rats. Int $\mathrm{J}$ Appl Res Nat Prod 2008; 1: 13-4.

5. Lalau JD, Race JM. Metformin and lactic acidosis in diabetic humans. Diabetes Obes Metab 2000; 2: 131-7.

6. Kavishankar GB, Lakshmidevil N, Mahadeva Murthy S, Prakash HS, Niranjana SR. Diabetes and medicinal plants - a review. Int J Pharm Biomed Sci 2011; 2: 65-80.

7. Marles R, Farnsworth N. Antidiabetic plants and their active constituents. Phytomedicine 1995; 2: 137-89.

8. Nathan D. Long-term complications of diabetes mellitus. N Engl J Med 1993; 23: 1676-85.

9. García-González M, Morales TC, Ocampo R, Pazos L. Subchronic and acute preclinic toxicity and some pharmacological effects of the water extract from leaves of Petiveria alliacea (Phytolaccaceae). Int J Trop Biol 2006; 54: 1323-6.

10. Lopes-Martins RA, Pegoraro DH, Woisky R, Penna SC, Sertie JA. The anti-inflammatory and analgesic effects of a crude extract of Petiveria alliacea L. (Phytolaccaceae). Phytomedicine 2002; 9: 245-8.

11. Williams LAD, Rosner H, Levy HG, Barton EN. A critical review of the therapeutic potential of dibenzyl trisulphide isolated from Petiveria alliacea L (guinea hen weed, anamu). West Indian Med J 2007; 56: 17 21.

12. Benevides PJ, Young MC, Giesbrecht AM, Roque NF, Bolzani VS. Antifungal polysulphides from Petiveria alliacea L. Phytochemistry 2001; 57: 743-7.

13. Carina SM, Valéria WT, Álvaro ACT, Nicodemos TPF. Analysis of fetal and placental development in rats after administration of hydroalcoholic extract from the root of Petiveria alliacea L. (Phytolaccaceae). Int $\mathbf{J}$ Morphol 2010; 28: 165-9.

14. Lores RI, Cires Pujol M. Petiveria alleaceae L (anamu). Study of the hypoglycemic effect. Med Interne 1990; 28: 347-52.
15. Jarald EE, Joshi SB, Jain DC. Antidiabetic activity of flower buds of Michelia champaca Linn. Indian J Pharmacol 2008; 40: 256-60.

16. Kumar N, Gupta AK, Prakash D, Kumar P. Hypoglycemic activity of Onosma hispidum (Ratanjot). Int J Diabetes Dev Ctries 2010; 30: 213 6.

17. Pattanayak S, Nayak SS, Panda D, Shende V. Hypoglycemic of Canajus scarabaeoides in glucose overloaded and Streptozotocininduced diabetic rats. Bangladesh J Pharmacol 2009; 4: 131-5.

18. Etuk EU. Animal models for studying diabetes mellitus. Agric Biol J N Am 2010; 1: 130-4.

19. Rathod NR, Chitme HR, Irchhaiya R, Chandra R. Hypoglycemic effect of Calotropis gigantea Linn. leaves and flowers in Streptozotocininduced diabetic rats. Oman Med J 2011; 26: 104-8.

20. Monache FD, Suarez L. 6-C-formyl and 6-C-hydroxymethyl flavanones from Petiveria alliacea. Phytochemistry 1992; 31: 2481-2.

21. Kubec R, Musah R. Cysteine sulfoxide derivatives in Petiveria alliacea. Phytochemistry 2001; 58: 981-5.

22. Musah R, He Q, Kubec R, Jadhav A. Studies of a novel cysteine sulfoxide lyase from Petiveria alliacea: the first heteromeric alliinase. Plant Physiol 2009; 151: 1304-16.

23. Segelman FP, Segelman AB. Constituents of Petiveria alliacea L (Phytoloccaceae). Part I. Isolation of isoarborinol, isoarborinol acetate and isoarborinol cinnamate from the leaves. Lloydia 1975; 38: 537.

24. Urueña C, Cifuentes C, Castañeda D, Arango A, Kaur P, Asea A et al. Petiveria alliacea extracts uses multiple mechanisms to inhibit growth of human and mouse tumoral cells. BMC Complement Altern Med 2008; 8: 1-17.

25. Juárez-Rojop I, Díaz-Zagoya J, Ble-Castillo J, Miranda-Osorio P, Castell-Rodríguez A, Tovilla-Zarate $\mathrm{C}$ et al. Hypoglycemic effect of Carica papaya leaves in streptozotocin-induced diabetic rats. BMC Complementary Altern Med 2012; 12: 1-11.

26. Kwon O, Eck P, Chen S, Corpe C, Lee J, Kruhlak M et al. Inhibition of the intestinal glucose transporter GLUT2 by flavonoids. JASEB J 2007; 21: $366-77$

27. Kottra G, Daniel H. Flavonoid glycosides are not transported by the human $\mathrm{Na}+$ /glucose transporter when expressed in Xenopus laevis oocytes, but effectively inhibit electrogenic glucose uptake. J Phamacol Exp Ther 2007; 322: 829-35.

28. Cifuente MC, Castañed DM, Urueñ CP, Fiorentino S. A fraction from Petiveria alliacea induces apoptosis via a mitochondria-dependent pathway and regulates HSP70 expression. Univ Sci 2009; 14: 125-34. 